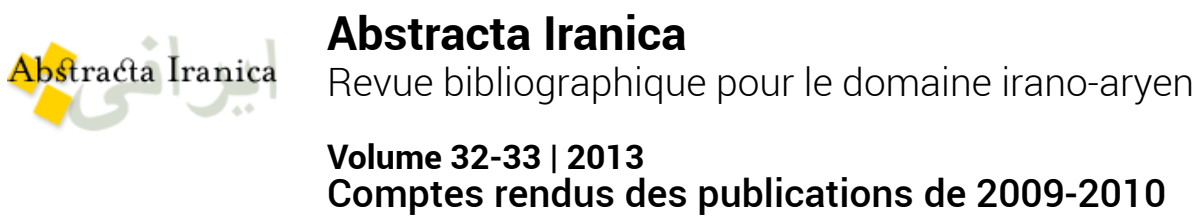

\title{
Josette Elayi, André Lemaire. Le trésor de Byblos TIX
}

\section{Astrid Nunn}

\section{(2) OpenEdition}

\section{Journals}

Édition électronique

URL : http://journals.openedition.org/abstractairanica/40249

DOI : 10.4000/abstractairanica.40249

ISSN : 1961-960X

Éditeur :

CNRS (UMR 7528 Mondes iraniens et indiens), Éditions de l'IFRI

Édition imprimée

Date de publication : 1 décembre 2013

ISSN : 0240-8910

\section{Référence électronique}

Astrid Nunn, « Josette Elayi, André Lemaire. Le trésor de Byblos TIX», Abstracta Iranica [En ligne],

Volume 32-33 | 2013, document 59, mis en ligne le 01 juillet 2016, consulté le 05 octobre 2020. URL

http://journals.openedition.org/abstractairanica/40249; DOI : https://doi.org/10.4000/

abstractairanica.40249

Ce document a été généré automatiquement le 5 octobre 2020.

Tous droits réservés 


\title{
Josette Elayi, André Lemaire. Le trésor de Byblos TIX
}

\author{
Astrid Nunn
}

\section{RÉFÉRENCE}

Josette Elayi, André Lemaire. « Le trésor de Byblos TIX ». Trans. 38, 2009, p. 77-98.

1 Un second trésor de monnaies est présenté dans Trans. 38. Il s'agit du premier trésor découvert par M. Dunand dans le « quartier N.-O. » de Byblos en 1931. Cet article en est la première publication aussi complète que les circonstances le permettent. Des rois de Byblos, il compte e.a. 139 sicles de 'Ozba'al, 30 sicles de 'Addirmilk/“Urimilk et 49 sicles d"Aynel.

\section{AUTEURS}

\section{ASTRID NUNN}

Université de Munich 